\title{
Transformasi Pendidikan Ilmu Pengetahuan Sosial dalam Menghadapi Era Revolusi Industri 4.0
}

\author{
Aulia Nursyifa ${ }^{\mathrm{a}, 1 *}$ \\ aProgram Studi Pendidikan Pancasila dan Kewarganegaraan, \\ Fakultas Keguruan dan Ilmu Pendidikan, Universitas Pamulang, Tangerang Selatan \\ 1aulianursyifa@unpam.ac.id \\ *korespondensi penulis
}

Naskah diterima: 07-01-19, direvisi: 23-02-19, disetujui: 26-03-19

DOI: http://dx.doi.org/10.32493/jpkn.v6i1.y2019.p51-64

\begin{abstract}
Abstrak
Era revolusi industri 4.0 menjadi fenomena penting di berbagai bidang termasuk dalam bidang pendidikan. Permasalahan yang dihadapi dalam era ini siswa tidak hanya dituntut menggunakan teknologi digital, namun kualitas sumber daya manusia harus lebih ditingkatkan agar mampu beradaptasi dari perubahan. Artikel ini merupakan kajian literatur yang bertujuan untuk mengungkapkan tantangan Pendidikan IPS dalam menghadapi era revolusi industri 4.0. Hasil kajian ini mengungkapkan bahwa pendidikan IPS sebagai bekal dalam menghadapi perubahan zaman, pengajaran IPS bukan hanya konsep atau teori, tetapi implementasi dari pendidikan IPS menjadi pedoman bagi siswa untuk dapat memecahkan persoalan sosial. Pengajaran IPS harus bertransformasi menjadi pembelajaran yang menarik dan menyenangkan, kreatif, menumbuhkan rasa ingin tahu yang tinggi, berpikir kritis, berpendapat, kolaborasi dalam tim, kepekaan sosial, dan kemampuan pemecahan masalah. Peran pendidikan IPS tidak hanya sekedar membuat peserta didik cerdas, namun juga menjadi warga negara yang baik, berjiwa sosial, berakhlak, dan berkarakter. Oleh karena itu, dalam menghadapi tantang di era ini diperlukan kolaborasi semua pihak meliputi: sekolah, keluarga, masyarakat, serta pemerintah dalam rangka meningkatkan kualitas pendidikan di era revolusi industri 4.0.
\end{abstract}

Kata-kata kunci: transformasi pendidikan; ilmu pengetahuan sosial; revolusi industri

\footnotetext{
Abstract

The era of industrial revolution 4.0 became an important phenomenon in various fields including in the field of education. Problems faced in this era students are not only required to use digital technology, but the quality of human resources must be improved in order to be able to adapt to change. This article is a literature review that aims to reveal the challenges of social studies education in facing the era of industrial revolution 4.0. The results of this study reveal that social studies education as a provision in facing changing times, social studies teaching is not only a concept or theory, but the implementation of social studies education becomes a guideline for students to be able to solve social problems. Social studies teaching must be transformed into interesting and fun, creative learning, fostering high curiosity, critical thinking, opinion, team collaboration, social sensitivity, and problem solving skills. The role of social studies is not only to make students smarter, but also to be good citizens, social-minded, moral, and with character. Therefore, in facing challenges in this era, collaboration between all parties is needed including: schools, families, communities, and the government in order to improve the quality of education in the era of industrial revolution 4.0.
}

Keywords: education transformation; social sciences; the industrial revolution 


\section{Pendahuluan}

Era revolusi industri 4.0 menjadi perbincangan hangat di berbagai kalangan di dunia, eksistensi keberadaannya terus bertransformasi di berbagai bidang kehidupan seperti dalam bidang ekonomi, politik, teknologi, sosial, budaya, dan termasuk di bidang pendidikan. Revolusi industri 4.0 dikemukakan oleh Schwab (2016), dalam bukunya "The Fourth Industrial Revolution" dipaparkan bahwa pada tahun 1760 terjadi revolusi industri pertama ditandai dengan penemuan rel kereta api dan mesin uap, pada akhir abad 19 revolusi industri kedua ditandai dengan munculnya listrik, pada tahun 1960 terjadi revolusi ketiga ditandai dengan lahirnya komputer atau disebut revolusi digital, sedangkan pada abad 21 disebut sebagai Revolusi Industri 4.0 yang ditandai dengan mobile dan internet.

Pada era ini juga ditandai dengan adanya kemajuan dari komputerisasi data, smartphone,internet, kecerdasan buatan, bioteknologi, robotisasi, dan sebagainya. Fenomena revolusi industri 4.0 ini menjadikan manusia memiliki ketergantungan pada teknologi terutama internet, maka dikenal dengan istilah internet of things, dimana internet dapat memudahkan kehidupan manusia dalam komunikasi jarak jauh menjadi dekat, mencari berbagai informasi menggunakan internet, sebagai sarana belajar untuk menambah literasi bisa didapatkan lewat internet, internet juga dijadikan media yang paling banyak digunakan untuk berbisnis, dan berbagai keunggulan lainnya.
Era Revolusi industri 4.0 menjadi perbincangan hangat di berbagai belahan dunia bahkan Bangsa Indonesia saat ini telah mempersiapkan diri dalam menghadapi perubahan zaman tersebut, sebagaimana yang dipaparkan oleh Menteri Riset, Teknologi, dan Pendidikan Tinggi Mohamad Nasir (Ristekdikti 2018) menjelaskan, "Indonesia menjadi negara yang memiliki potensi yang tinggi untuk menghadapi revolusi industri 4.0". Berbagai macam upaya yang ditempuh bangsa Indonesia dalam menghadapi era revolusi industri 4.0, meskipun dalam prakteknya masih terdapat persoalan yang harus dihadapi.

Keberadaan era revolusi industri 4.0 merubah wajah baru pendidikan Indonesia, pendidikan terus bertransformasi mengikuti perkembangan zaman. Namun setiap perubahan pasti akan membawa dampak bagi kehidupan sehingga hal tersebut menjadi sebuah tantangan yang harus dihadapi. Sebagaimana yang diungkapkan Riyana (2018) bahwa terdapat "tantangan yang harus dihadapi dunia pendidikan di era revolusi industri 4.0 dapat dilihat dari cara berpikir, cara belajar, cara bertindak para peserta didik dalam rangka mengembangkan berbagai inovasi dan kreativitas dalam pendidikan". Oleh karena itu, keberadaan era revolusi industri 4.0 menjadi sebuah tantangan yang harus dihadapi untuk menghasilkan pendidikan yang bermutu dan berkualitas di masa yang akan datang.

Revolusi industri 4.0 bukanlah sebuah ancaman jika manusianya dapat memanfaatkan momentum tersebut 
secara positif dan benar, bahkan keberadaanya membawa manusia ke arah kemajuan terutama dalam bidang pendidikan misalnya keberadaan pembelajaran secara online atau elearning, penggunaan smartphone dalam belajar, penggunaan internet dalam mencari berbagai literasi dalam pembelajaran, dan berbagai media pembelajaran yang sudah berbasis teknologi yang dapat membantu dalam proses belajar. Namun disisi lain perubahan era revolusi industri ini, membuat manusia menjadi dehumanisasi karena diperbudak oleh teknologi terutama bagi generasi muda yang menjadikan era ini sebagai era kebebasan tanpa nilai dan norma sosial, misalnya: munculnya cyber bullying di media sosial, terjadi kenakalan dan kriminalitas di kalangan remaja, penyalahgunaan internet dengan mudahnya mengakses video porno, kecanduan game online sampai melupakan kehidupan nyatanya, dan berbagai permasalahan sosial lainnya.

Permasalahan tersebut sangat penting untuk dikaji secara komprehensif, karena pada dasarnya kemajuan sebuah pendidikan bukan terletak dari keunggulan sarana dan prasarana serta teknologi yang canggih, namun juga harus dilengkapi dengan keunggulan dari segi sumber daya manusia yang berkualitas. Para pendidik berupaya untuk memberikan bekal kepada peserta didik untuk menjadikan peserta didik manusia yang seutuhnya.

Hal ini selaras tujuan pendidikan Indonesia yang termaktub dalam UndangUndang RI No.20 Tahun 2003 mengenai
Sistem Pendidikan Nasional yaitu "pendidikan nasional berfungsi untuk mencerdaskan kehidupan bangsa, bertujuan untuk mengembangkan potensi peserta didik agar menjadi manusia beriman dan bertakwa kepada Tuhan Yang Maha Esa, berakhlak mulia, berilmu, sehat, cakap, kreatif, mandiri, dan menjadi warga negara yang demokratis dan bertanggung jawab".(Kemendikbud: 2003).

Berdasarkan undang tersebut tujuan dari sebuah pendidikan bukan hanya membuat siswa menjadi pintar, namun dalam menghadapi era sekarang ini dibutuhkan kompetensi lainnya sehingga dapat menjadikan siswa sebagai generasi yang berkualitas yang dapat menyongsong masa depan. Implementasi dari pendidikan ilmu sosial yang penting yaitu mencetak generasi muda untuk menjadi warga negara yang baik, bertanggung jawab, dan berjiwa sosial. Hal tersebut tidak akan terwujud tanpa adanya bantuan dari guru, meskipun di era ini teknologi sangat mendominasi dalam pendidikan namun peran guru sangatlah penting sebagai agent of change dalam mencapai tujuan pendidikan, terutama adanya era revolusi industri 4.0 maka guru memiliki peran untuk menjembatani kebutuhan siswa dengan keberhasilan belajarnya ( $\mathrm{Mz}$ dan Rahmawati, 2019). Oleh karena itu cara pengajaran guru harus dapat menyesuaikan diri dengan tuntutan zaman dan disesuaikan dengan kebutuhan peserta didik di era revolusi industri 4.0.

Tujuan yang ingin dicapai dalam artikel ini adalah mengungkapkan berbagai tantangan pendidikan IPS dalam 
menghadapi era revolusi industri. Oleh karena itu, pendidikan IPS harus bertransformasi dalam memenuhi berbagai tuntutan masyarakat dan menjadi pedoman keilmuan untuk dapat diimplementasikan dalam kehidupan nyata. Bagaimana tantangan menghadapi perubahan pendidikan IPS dalam era revolusi industri 4.0. Hasil kajian pustaka ini diharapkan dapat memberikan masukan terhadap guru IPS dalam memberikan pengajaran kepada peserta didik yang disesuaikan dengan tuntutan zaman.

\section{Metode}

Metode yang digunakan dalam artikel ini yaitu kajian literatur terkait dengan transformasi pendidikan IPS dalam menghadapi revolusi industri 4.0. Berbagai kajian literatur yang digunakan dalam artikel ini berupa: berbagai referensi buku, artikel jurnal, prosiding seminar, dan berbagai naskah akademik lainnya. Berbagai data kajian literasi tersebut, dikumpulkan dan pada selanjutnya dilakukan analisis kajiannya.

Tujuan analisis literatur ini yaitu untuk memperkuat kemampuan berpikir terhadap berbagai teori dari para ahli maupun hasil kajian penelitian yang relevan. Sehingga dengan adanya berbagai kajian tersebut menjadi pondasi dasar gagasan tentang pendidikan IPS dalam menghadapi era revolusi industri 4.0.

\section{Hasil dan Pembahasan}

Perubahan dunia dalam era revolusi industri 4.0 menjadi sebuah topik yang sangat penting untuk dikaji, bahkan eksistensinya sampai saat ini masih sering menjadi perdebatan bagi para ahli dan masih dianggap ambigu atau tidak jelas. Seiring dengan berjalannya waktu maka keberadaan revolusi industri 4.0 menjadi sebuah fenomena yang harus dijalani.

Menurut Gleason (2018) "masyarakat dunia saat ini mengalami masa transisi untuk itu perlu adanya adaptasi untuk menjalani era revolusi industri 4.0". Melakukan adaptasi dari setiap perubahan membutuhkan kerja keras agar semua berjalan saling berdampingan dan tidak menimbulkan permasalahan dikemudian hari. Namun sayangnya perubahan teknologi bergerak lebih progresif dibandingkan dengan sumber daya manusianya.

Lembaga pendidikan menjanjikan sebuah solusi yang dianggap masyarakat sebagai pencerahan kearah yang lebih baik lagi. Nyatanya tetap saja pendidikan masih berada posisi tertinggal jika dibandingkan dengan perubahan zaman. Oleh karena itu, dunia pendidikan terus berbenah melakukan banyak perubahan dalam dirinya, berikut ini akan dipaparkan berbagai transformasi pendidikan IPS dalam menjawab tantangan zaman.

\section{Transformasi dalam Pengajaran IPS}

Pengajaran IPS harus bertransformasi menjadi pengajaran yang menarik dan menyenangkan, oleh karena itu peran guru sangat penting untuk melakukan banyak perubahan mulai dari berubahnya mindset, media pembelajaran, metode mengajar, update informasi, menguasai teknologi, menguasai literasi, dan sebagainya. 
Pengajaran IPS harus bertransformasi untuk dapat mempersiapkan siswa dalam menghadapi era perubahan zaman, pengajaran IPS bukan hanya tataran konseptual atau teoritis tetapi yang terpenting adalah implementasi dari pendidikan IPS menjadi pedoman bagi siswa untuk dapat memahami kehidupan sosial sehingga dapat memecahkan persoalan yang terjadi di masyarakat.

Pengajaran konvensional yang sering dilakukan guru IPS yaitu menggunakan metode mengajar dengan ceramah, ditambah lagi cara mengajar guru hanya satu arah, guru menggunakan teknik menghafal untuk mengingat pelajaran, mencatat materi, mempelajari Lembar Kerja Siswa (LKS), siswa kurang berpikir kritis, pengajaran yang hanya menekankan aspek kognitif namun aspek afektif serta psikomotorik kurang ditekankan, pengajarannya bukan mementingkan proses, dan berbagai pengajaran IPS lainnya.

Akibatnya pengajaran yang demikian mata pelajaran IPS dianggap sebagai mata pelajaran yang jenuh dan membosankan bagi siswa. Maka berbagai pengajaran seperti itu sudah tidak relevan lagi, seorang guru dapat menggunakan berbagai pengajarannya dengan berbagai cara dan disesuaikan dengan kondisi siswa saat ini misalnya penerapan pengajaran student centered learning, diskusi, pengajaran yang menitik beratkan pada studi kasus dan pemecahan masalah, model pengajaran inquiry, pengajaran problem based learning, cooperative learning, role playing, dan sebagainya. Berbagai metode atau model pembelajaran tersebut dapat dilaksanakan dengan baik jika guru IPS memiliki keterampilan dalam pengimplementasiannya.

Guru pendidikan IPS harus bertransformasi menuju perubahan dan selalu mengupdate diri menyesuaikan dengan kemajuan zaman, oleh karena itu guru pendidikan IPS wajib mengembangkan diri agar tidak gagap teknologi. Siswa yang hidup pada era revolusi industri 4.0 ini adalah para generasi millenial yang disebut generasi $\mathrm{Z}$ yang lahir tahun 1995-2010 bahkan generasi Alpha yang lahir tahun 2010sekarang, mereka lahir disaat teknologi sedang berkembang dengan begitu pesatnya, sehingga siswa sudah familiar dengan penggunaan teknologi bahkan lebih pintar menggunakan teknologi daripada gurunya. Oleh karena itu, sebagai suatu keniscayaan bahwasanya seorang guru harus mengetahui penggunaan teknologi dalam pembelajaran dapat dilihat dari berbagai media pembelajaran IPS yang berbasis teknologi misalnya: memutarkan video pembelajaran, penggunaan slide presentasi, menggunakan gambar, memanfaatkan acara berita di televisi, internet menjadi media yang sangat penting agar siswa dapat memiliki beragam informasi tentang kajian keilmuan dalam IPS, guru juga dapat menggunakan media game disesuaikan dengan materi pembelajaran, dan berbagai media lainnya. Bahkan guru dapat menggunakan masyarakat secara langsung sebagai media pembelajaran dengan cara mengajak siswa untuk melakukan penelitian kepada masyarakat terkait 
dengan materi IPS yang sedang dipelajari misalnya dengan menugaskan siswa mewawancarai para pedagang di Pasar terkait dengan materi tentang Ekonomi dalam IPS, mewawancarai masyarakat terkait dengan permasalahan sosial di sekitar rumah siswa dalam pembelajaran Sosiologi.

Pengajaran pada era revolusi industri 4.0 terus bertransformasi ke arah kemajuan Ilmu Pengetahuan dan Teknologi. Menurut Garrison (2011) "pengajaran abad 21 ditandai dengan pengajaran yang difasilitasi secara online menggunakan teknologi jaringan disebut dengan e-learning". Pengajaran e-learning masih terdapat dalam pendidikan tinggi, namun tidak menutup kemungkinan siswa akan diarahkan ke pembelajaran virtual e-learning tersebut. Apalagi dengan adanya sarana pembelajaran melalui internet yang sangat diminati peserta didik misalnya Ruang Guru, Quipper, Youtube, Google, dan sebagainya. Dengan adanya kecanggihan teknologi tersebut memudahkan siswa untuk mengakses literasi yang berkaitan dengan pembelajaran bahkan berbagai informasi dapat dicari di internet. Atas dasar itulah membuat suatu pandangan bahwa seolah peran guru sudah digantikan dengan internet, oleh karena itu kompetensi guru harus terus ditingkatkan agar dapat menyesuaikan dengan kemajuan zaman.

Peran guru tidak akan pernah tergantikan dengan teknologi secanggih apapun, terutama dalam hal pengajaran akan nilai dari setiap pembelajaran, sebagai seorang guru tentunya wajib menasehati peserta didik agar tetap selalu menjunjung tinggi akan nilai-nilai yang berlaku dalam kehidupan di masyarakat serta implementasi dari pembelajaran tersebut harus ada sehingga pembelajaran lebih bermakna.

\section{Transformasi Pendidikan IPS dalam Keterampilan Abad 21}

Keberadaan era revolusi industri 4.0 dalam peningkatan ilmu pengetahuan dan teknologi nyatanya menjadi sebuah tantangan bagi kehidupan manusia, sebagaimana yang dijelaskan oleh Peters (2017) "keberadaan teknologi di era ini dapat menciptakan peningkatan pengangguran di dunia karena banyak orang akan kehilangan pekerjaan yang digantikan oleh teknologi." Hal ini menjadi kekhawatiran dan menjadi isu sosial yang paling banyak dibicarakan di abad 21, guru diharapkan dapat mengeksplorasi keterampilan yang dimiliki siswa sehingga dengan begitu siswa dapat menjadi manusia yang berkualitas.

Pendidikan mengajarkan keterampilan khusus yang nantinya akan dibutuhkan siswa di masa yang akan datang. Oleh karena itu, pendidikan IPS harus bertransformasi untuk memenuhi tuntutan zaman, terutama dalam penguasaan keterampilan khusus yang wajib dimiliki siswa.

Keterampilan dalam pendidikan IPS diungkapkan oleh Sapriya (2017: 51) "keterampilan yang dibutuhkan dalam dimensi pendidikan IPS meliputi: keterampilan dalam meneliti, keterampilan berpartisipasi sosial, 
terampil dalam berpikir, terampil dalam berkomunikasi". Terdapat kompetensi yang harus dimiliki dalam era revolusi industri 4.0, yaitu: (1). Kompetensi pribadi, kompetensi seseorang dalam pengembangan kognitif dan sistem nilai, memiliki sikap kritis dan adaptif terhadap perkembangan teknologi. (2).Kompetensi sosial, kompetensi yang dibutuhkan meliputi: kemampuan komunikasi, koneksi sosial, bekerja sama, dan membangun struktur sosial dengan individu dan kelompok lainnya (Wardini. 2018).

Pada abad 21 keterampilan yang dibutuhkan meliputi: siswa dituntut untuk memiliki kreativitas yang tinggi dan selalu menghasilkan berbagai inovasi; siswa diarahkan untuk dapat berfikir kritis terhadap berbagai persoalan dalam kehidupannya, memiliki rasa ingin tahu yang tinggi; siswa dapat memecahkan permasalahan sosial yang mereka hadapi; siswa memiliki kepekaan sosial dan rasa peduli terhadap sesama; siswa juga dituntut untuk dapat berkomunikasi baik sehingga mereka berpartisipasi aktif dalam kegiatan pembelajaran dan aktif mengeluarkan pendapat dan mampu berkomunikasi dengan lisan, tulisan, maupun lewat sosial media; siswa dituntut untuk dapat berkolaborasi atau bekerjasama dengan orang lain dalam tataran lokal, nasional, maupun global.

\section{Transformasi dalam Pendidikan Nilai dalam IPS}

Pada era revolusi industri 4.0 ini ditandai dengan masuknya budaya luar yang tidak sesuai dengan budaya bangsa masuk ke Indonesia yang tidak sesuai dengan budaya bangsa. Alhasil generasi muda banyak menduplikasi budaya luar ditambah lagi pondasi dasar generasi muda sangat lemah karena mereka masih melakukan pencarian identitas diri, sehingga banyak diantara mereka yang salah bergaul dan cenderung melakukan perbuatan yang melanggar nilai dan norma di masyarakat.

Pendidikan bukan hanya sebagai sarana untuk mentransfer keilmuan, namun juga menjadi sangat penting dalam mengatur kehidupan manusia sehingga dapat menjadi manusia yang dapat diterima dalam kehidupan masyarakat. Sebagaimana yang diungkapkan oleh Durkheim (Hidayat, 2014) "fungsi utama pendidikan adalah untuk mentransmisi nilai-nilai dan norma-norma di masyarakat". Nilai merupakan sesuatu yang berharga dan diyakini oleh manusia, sehingga keberadaan nilai dalam kehidupan sangat penting dan diwariskan dari satu generasi ke generasi lainnya di dalam kehidupan masyarakat.

Pendidikan IPS seyogyanya dapat menjadi pelopor untuk dapat membantu dalam menanamkan nilai-nilai dan normanorma sosial di masyarakat sehingga peserta didik dapat mengimplementasikan nilai-nilai dan norma sosial dalam kehidupan sehari-hari misalnya nilai sosial, nilai kebaikan, nilai religius, norma kesusilaan, norma agama, norma hukum, dan sebagainya. pengimplementasian nilai dalam kehidupan siswa menjadi pondasi dasar sebagai upaya preventif yang untuk menghindari siswa dari dampak negatif 
pergaulan remaja seperti seks bebas, narkoba, bullying, dan sebagainya.

Saat ini di berbagai informasi di media cetak maupun elektronik banyak sekali kasus-kasus yang muncul terkait dengan hilangnya rasa kemanusiaan yang ada pada diri manusia, misalnya: manusia saling membully, saling menjatuhkan, adu domba, tidak peduli dengan sesama, karena persoalan kecil dapat menjadi konflik sosial di masyarakat, bahkan manusia dapat saling membunuh satu sama lainnya. Gejala-gejala dehumanisasi dalam kehidupan masyarakat inilah sangat mengkhawatirkan, khususnya dikalangan generasi muda. Pendidikan pada dasarnya bertujuan untuk memanusiakan manusia, hal ini selaras dengan fokus kajian keilmuan sosial untuk mengkaji tentang masyarakat. Oleh karena itu, pendidikan IPS harus melihat pendekatan nilai-nilai humanis untuk dapat diimplementasikan dalam kehidupan peserta didik sehingga kelak antar peserta didik dapat hidup berdampingan satu sama lain.

Pendidikan IPS menjadi sarana untuk mensosialisasikan nilai-nilai sosial bagi generasi muda sehingga nanti generasi tersebut akan menjadi warga negara yang baik dan demokratis di Indonesia. Tujuan utama pendidikan IPS adalah mempersiapkan menjadi warga negara yang baik sehingga dapat membuat keputusan dan ikut berpartisipasi aktif di lingkungan masyarakat, bangsa, dan dunia (Sapriya, 2017). Guru IPS harus menjunjung tinggi nilai-nilai bangsa yang dapat menumbuhkan jiwa nasionalisme generasi muda misalnya nilai pancasila diimplementasikan ke dalam perbuatan nyata, selain itu nilai lainnya yaitu: memiliki jiwa sosial, saling tolong menolong, toleransi, berakhlak mulia, kejujuran,nilai moral, kerukunan, menjunjung tinggi kebenaran, dan sebagainya.

Nilai karakter berperan menjadi pondasi dasar bagi peserta didik dalam menghadapi era revolusi industri 4.0. Sebagaimana yang diungkapkan oleh Herwina (2018) "penguatan pendidikan karakter dapat membentengi arus globalisasi generasi muda dalam menghadapi era revolusi industri". Sebagai guru IPS memasukan nilai-nilai karakter dalam proses kegiatan belajar IPS misalnya religius, kreatif, jujur, kerja keras, mandiri, toleransi, rasa ingin tahu, peduli sosial, tanggung jawab, cinta damai, dan sebagainya.

Sebagai guru pendidikan IPS berkewajiban untuk mengaitkan materi IPS dengan pendidikan nilai baik secara implisit maupun secara eksplisit dalam proses pembelajaran. Pada hakikatnya penerapan pendidikan nilai pada pembelajaran IPS bertujuan untuk memberikan pendampingan kepada siswa untuk dapat mengembangkan nilai-nilai demokrasi dalam kehidupan masyarakat, maka dalam integrasi pendidikan nilai moral yang berpedoman pada pancasila dan nilai-nilai sosial sehingga peserta didik diharapkan dapat menjadi warga negara yang baik (Suhada, 2017). Kebermaknaan nilai dalam kehidupan generasi muda akan terus pahami dan yang terpenting bukan hanya sekedar retorika belaka namun nilai-nilai tersebut dapat diimplementasikan dalam 
Jurnal Pendidikan Kewarganegaraan

Vol. 6 No. 1 Maret 2019
Journal of Civics and Education Studies p-ISSN 2302-0865 | e-ISSN 2621-346X

kehidupan siswa sehari-hari. Sekolah berperan untuk dapat mentransmisikan nilai-nilai untuk generasi yang akan datang.

\section{Transformasi dalam Kualitas Guru IPS}

Kualitas guru dalam menghadapi era revolusi industri 4.0 harus ditingkatkan sesuai dengan kebutuhan zaman. Berbagai tuntutan yang ada pada diri guru menjadi sebuah tantangan yang harus dilalui sehingga guru di masa ini wajib untuk menjadi guru yang profesional, guru harus selalu mengupdate diri untuk selalu belajar dalam mengembangkan kemampuan mengajar, mengupdate keilmuan yang dimilikinya dengan melanjutkan pendidikan tinggi, mengupdate informasi terbarukan dalam pengetahuan IPS, bergabung dalam perkumpulan guru IPS dalam Musyawarah Guru Mata Pelajaran (MGMP) IPS, mengikuti berbagai seminar maupun workshop, pelatihan, dan berbagai kegiatan lainnya yang dapat menambah pengetahuan dan wawasan guru agar dapat menjadi guru yang diharapkan di masa ini.

Guru IPS di abad 21, wajib memiliki kemampuan dalam penggunaan teknologi sebagai media pembelajaran, karena di zaman ini guru harus menghadapi siswa yang sudah terbiasa menggunakan teknologi dalam hidupnya sehingga guru yang tidak mengerti teknologi sangat kesulitan mengajar di abad ini. Apalagi dengan adanya sistem belajar yang berbasis teknologi seperti e-learning, ujian yang sudah berbasis komputer, penilaian dengan menggunakan e-rapor, media pembelajaran yang menggunakan proyektor, laptop, dan sebagainya. Hal ini membuat guru diharapkan untuk dapat menggunakan media tersebut dengan baik. Atas dasar itu, disinilah peran guru IPS sebagai mediator yang dapat memahami dan dapat menggunakan berbagai media pembelajaran dalam pendidikan IPS.

Dalam menghadapi era ini guru diharapkan menjadi inovator yang dapat melahirkan berbagai inovasi tinggi untuk mengembangkan kreativitas dalam mengajar, sehingga keunggulan tersebut akan melahirkan hal-hal yang baru dan kreatif dalam pembelajaran IPS, guru kreatif akan menggunakan beragam model dan metode mengajar yang dapat disesuaikan dengan tujuan pembelajaran yang diinginkan serta disesuaikan dengan tuntutan global.

Guru sebagai fasilitator yang dapat memfasilitasi para siswa dalam pembelajaran IPS, memfasilitasi dalam memperoleh informasi terkait dengan keilmuan IPS di berbagai sumber literasi buku maupun digital. Menurut Gunawan (2016: 95), "guru yang bersifat konstruktivis yaitu guru yang dapat memfasilitasi siswa untuk, menganalisis, dan mengolah berbagai informasi dari berbagai sumber yang diterima oleh siswa".

Dalam kegiatan pembelajaran IPS guru dapat memfasilitasi siswa agar dapat berpartisipasi aktif dengan menggali informasi dari berbagai referensi maupun dari pengalaman siswa sendiri, sehingga berdasarkan pengalamannya siswa dapat secara langsung melihat berbagai 
fenomena sosial di lingkungan sekolah, pergaulan teman sebaya, lingkungan keluarga maupun lingkungan masyarakat. Atas dasar itulah, seorang guru harus membimbing siswa agar dapat menguasai dan memanfaatkan keilmuan sosial yang dimiliki. Selain itu, guru memfasilitasi siswa untuk menciptakan suasana belajar yang kondusif dan menyenangkan.

Menghadapi peserta didik di era ini, tidak bisa disamakan dengan pada tempo dahulu. Oleh karena itu, guru yang otoriter dan ditakuti di era ini sudah tidak relevan lagi. Namun guru harus dapat menempatkan diri ada saatnya guru harus tegas dan ada saatnya menjadi sahabat yang baik bagi siswa, menjadi orangtua kedua bagi siswa, guru juga harus memiliki kepribadian baik, berbudi pekerti luhur, jujur, akhlak yang baik. Guru menjadi contoh apa yang diucapkan dan apa yang diperbuat sehingga guru menjadi idola di mata siswa. Guru IPS harus memiliki jiwa sosial yang tinggi dan menerapkan aturan nilai dan norma sosial dalam kehidupan sehari-hari.

Guru menjadi motivator yang selalu memberikan motivasi bagi peserta didik, yang selalu mengarahkan kepada hal-hal yang baik. Sehingga guru seperti inilah yang dapat menginspirasi siswa untuk menggapai cita-cita di masa depan.

Guru sebagai evaluator memberikan penilaian tidak hanya penilaian pengetahuan kognitif di bidang IPS, namun juga dalam ranah afektif, dan psikomotorik siswa. Penilaian siswa tidak menitikberatkan dalam penilaian hasil yang diraih siswa namun juga penilaian proses dalam kegiatan belajar siswa.
Apalagi dengan adanya keilmuan sosial yang dipelajari siswa, maka siswa dinilai secara komprehensif dalam aktivitas sosialnya sehingga guru dapat mengamati apakah keilmuan sosial dapat diimplementasikan dalam kehidupan sehari-hari siswa.

\section{Transformasi Kurikulum Pendidikan IPS}

Seiring dengan perubahan zaman, maka manusia terus bertransformasi melakukan berbagai perubahan dalam kehidupan terutama dalam kemajuan dibidang teknologi. Namun yang menjadi dilematis ketika perubahan perkembangan begitu cepat tetapi tidak disesuaikan dengan sumber daya manusianya. Pendidikan menjadi salah satu harapan besar agar masyarakat agar dapat mengimbangi kemajuan yang ada.

Menurut Durkheim (Hidayat. 2014) "sekolah adalah miniatur dari kehidupan masyarakat". Sekolah menjadi jalan untuk mempersiapkan individu agar dapat terjun ke dalam kehidupan masyarakat. Jika sekolah dapat mencetak generasi muda yang berkualitas maka akan berpengaruh terhadap kemajuan sebuah bangsa yang berkualitas juga.

Pada dasarnya kurikulum pendidikan IPS diarahkan agar siswa dapat menjadi warga negara yang baik, dalam kondisi masyarakat global yang terus mengalami perubahan menjadi tantangan bagi pendidikan IPS agar mampu beradaptasi dalam perubahan. Hal ini selaras dengan pendapat Gunawan (2016) "IPS harus dirancang dalam kurikulum untuk membangun kemampuan siswa dalam 
kehidupan masyarakat yang selalu mengalami perubahan". Berbagai perubahan akibat kemajuan ilmu pengetahuan dan teknologi akan berdampak bagi kehidupan baik yang berdampak positif maupun negatif. Dampak inilah yang menjadi sebuah tantangan bagi siswa yang sejak dini mengenal kehidupan sosial sehingga nantinya peserta didik dapat menghadapi berbagai perubahan dalam tataran lokal, nasional, maupun global. Kurikulum IPS bertransformasi memenuhi 3 ranah tersebut, oleh karena itu peran kurikulum IPS sangat penting dalam membawa perubahan dalam kehidupan manusia dalam menjawab tantangan zaman.

Kurikulum 2013 yang diterapkan saat ini di Indonesia, berusaha untuk menjawab berbagai fenomena kemajuan zaman yang ada. Peserta didik tidak hanya diarahkan dalam kurikulum untuk memiliki kecerdasan dalam memanfaatkan kemajuan di bidang ilmu pengetahuan dan teknologi, tetapi mereka juga dituntut untuk memiliki kemampuan dalam pengembangan kualitas diri manusia yang disebut dengan soft skill. Dalam kurikulum 2013 harus memberikan keseimbangan antara soft skill dan hard skill (Supardan. 2015).

Kemampuan hard skill berkaitan dengan kemampuan manusia dalam penguasaan ilmu pengetahuan dan teknologi dengan berbagai keilmuan yang dipelajari di bangku sekolah, sedangkan kemampuan soft skill diarahkan untuk dapat memiliki kepribadian yang baik dan dapat berhubungan dengan orang lain dalam kehidupan sosial. Oleh karena itu, kurikulum IPS harus diarahkan untuk dapat mengintegrasi kedalam kedua kemampuan tersebut secara seimbang.

Selama ini kelemahan dari implementasi kurikulum pendidikan IPS ini hanya menekankan pada tataran konseptual atau teoritis, jika menyesuaikan dengan kemajuan ilmu pengetahuan maka pembelajaran IPS dapat diarahkan kepada pendekatan scientific.

Pembelajaran scientific dalam IPS dapat dikembangkan dengan fakta sosial di masyarakat, siswa diarahkan untuk berfikir kritis terhadap permasalahan sosial yang terjadi, siswa dapat berpikir analisis sesuai fakta disesuaikan dengan pendekatan teoritis, memecahkan berbagai permasalahan sosial dalam lingkungan sosial terdekat siswa, dan berbagai pendekatan scientific lainnya.

Penerapan pendekatan scientific dalam kurikulum IPS dapat disesuaikan dengan tingkat perkembangan peserta didik dan jenjang pendidikan agar implementasi dari pembelajaran tersebut dapat terealisasi, di contohkan dalam pelajaran IPS siswa dapat melakukan mini riset tentang proses jual beli di pasar, atau dalam pelajaran Sosiologi dapat melakukan riset tentang penggunaan gadget di kalangan siswa. Setelah siswa selesai meneliti persoalan di sekitarnya maka siswa dapat mempresentasikan hasil penelitiannya kepada siswa lainnya di depan kelas.

Kurikulum IPS di Indonesia harus bertransformasi mengikuti perubahan zaman kearah kemajuan teknologi. Siswa dituntut untuk dapat beradaptasi dengan kebutuhan zaman, kurikulum dapat 
dirancang mempersiapkan generasi muda untuk dapat berperan di dalam kehidupan masyarakat. Kedepannya, siswa tidak hanya dituntut pintar namun dituntut untuk mempersiapkan keterampilanketerampilan yang dimilikinya, terutama dalam penguasaan teknologi. Dampak perubahan teknologi tanpa dilandasi dengan kekurangan keterampilan yang dimiliki maka mengakibatkan pengangguran secara massal, untuk itu perlu adanya reformasi dalam pendidikan dalam mempersiapkan generasi selanjutnya untuk mendapatkan pekerjaan di masa depan dalam era revolusi industri 4.0 (Schwab dan Samans, 2016: v).

Kurikulum IPS kedepannya dapat terintegrasi dengan dunia kerja, serta berbagai keterampilan-keterampilan yang wajib dimiliki siswa perlu ditingkatkan sehingga siswa dapat menjadi pribadi yang mandiri menciptakan lapangan kerja sendiri. Kurikulum harus dapat mengeksplor berbagai kemampuan siswa bukan hanya dalam kegiatan akademik tetapi juga mempersiapkan siswa untuk menjadi anggota masyarakat. Guru dalam mengajar mata pelajaran Ekonomi bukan hanya menekankan konsep materi ekonomi tetapi juga mengembangkan keterampilan siswa untuk memiliki kemampuan enterpreneur muda di masa depan. Oleh karena itu, pemerintah harus berupaya untuk merancang kurikulum yang dapat mempersiapkan generasi muda agar memiliki pekerjaan di masa depan dengan berbagai keterampilan yang dimilikinya.

Menghadapi berbagai tantangan di era ini diperlukan kolaborasi semua pihak seperti: sekolah, keluarga, masyarakat, serta pemerintah dalam rangka meningkatkan kualitas pendidikan di era revolusi industri 4.0. Tidak semudah mengembalikan telapak tangan untuk melakukan perubahan, namun berbagai perubahan tersebut dapat dimulai sejak dini dan dari hal terkecil sampai membawa perubahan besar bagi kehidupan manusia di masa yang akan datang.

\section{Kesimpulan}

Tantangan pada era revolusi industri 4.0 sangat besar bagi kehidupan. Pendidikan sebagai agent of change menghasilkan sumber daya manusia yang berkualitas yang dapat beradaptasi dengan tuntutan zaman. Dalam menjawab tantangan zaman tersebut pendidikan IPS diharapkan dapat melakukan transformasi agar berguna bagi kehidupan siswa dalam tataran pergaulan lokal, nasional, maupun global. Berdasarkan hasil kajian diatas terdapat transformasi yang dapat dilakukan: yaitu (1) perubahan dalam pengajaran IPS dari konvensional ke arah pengajaran berbasis teknologi, penerapan berbagai media dan metode pembelajaran yang sesuai dengan kemajuan zaman. Namun seberapa canggih teknologi dalam pendidikan,tak akan mampu menggantikan peran guru terutama dalam pengajaran akan nilai. (2) pengembangan keterampilan yang dimiliki siswa dalam menghadapi era revolusi diantaranya: kreativitas, inovasi, berpikir kritis, memecahkan permasalahan sosial, kemampuan berkomunikasi, berkolaborasi dengan sesama. 
penguatan dalam pendidikan nilai yang dapat diimplementasikan dalam kehidupan sehari-hari, siswa dapat menjadi warga negara yang baik, berjiwa sosial, berakhlak, dan berkarakter. (4) peningkatan profesionalitas guru. Guru dalam era digital yang dapat menguasai berbagai peran meliputi: guru sebagai mediator, inovator, fasilitator, evaluator, motivator, dan sebagainya. pengembangan kurikulum IPS harus disesuaikan dengan kebutuhan zaman, menyeimbangkan antara hard skill dan soft skill dalam pembelajaran, dan pembelajaran IPS dengan pendekatan scientific. Berbagai perubahan tersebut tidak akan terlaksana jika tidak adanya kerjasama dari berbagai pihak meliputi: pihak sekolah, keluarga, masyarakat, serta pemerintah dalam rangka meningkatkan kualitas pendidikan di era revolusi industri 4.0.

\section{Referensi}

Garrison, D. R. (2011). E-Learning in the 21st Century. New York: Routledge.

Gleason, N. W. (2018). Higher Education in the Era of the Fourth Industrial Revolution. Singapore.

https://doi.org/https://doi.org/10.10 07/978-981-13-0194-0.

Gunawan, R. (2016). Pendidikan IPS Filosofi, Konsep, dan Aplikasi. Bandung: Alfabeta.

Herwina, I. (2018). "Penguat Pendidikan Karakter Perspektif Islam dalam Era Milenial IR. 4.0." In Seminar Nasional Membangun SInergitas dalam Penguatan Pendidikan Karakter pada Era IR 4.0, 300. Jakarta: Universitas Muhammadiyah Jakarta.
Hidayat, R. (2014). Sosiologi Pendidikan Emile Durkheim. 1 ed. Jakarta: Grafindo.

Mz, S., \& Rahmawati, F. (2019). "Peran Guru dalam Penggunaan Multimedia Interaktif di Era Revolusi Industri 4.0." Prosiding Seminar Nasional Pendidikan Pascasarjana Universitas PGRI Palembang.

Peters, M. A. (2017). “Technological unemployment: Educating for the fourth industrial revolution Technological unemployment: Educating for the fourth industrial." Educational Philosophy and Theory 1857: $1-6$.

https://doi.org/10.1080/00131857.20 16.1177412 .

Ristekdikti. (2005). Undang-undang No. 14 Tahun 2005 Tentang Guru dan Dosen. http://kelembagaan.ristekdikti.go.id/ wpcontent/uploads/2016/08/UU_no_ 20_th_2003.pdf.

. 2018. "Era Revolusi Industri 4.0, Saatnya Generasi Millennial Menjadi Dosen Masa Depan.” 2018. http://sumberdaya.ristekdikti.go.id/in dex.php/2018/01/30/era-revolusiindustri-4-0-saatnya-generasimillennial-menjadi-dosen-masadepan.

Riyana, C. (2018). “Tantangan Pendidikan

Era Revolusi Industri." Universitas Negeri Malang. 2018. https://um.ac.id/content/page/2/201 8/11/tantangan-pendidikan-erarevolusi-industri-4-0.

Sapriya. (2017). Pendidikan IPS Konsep dan Pembelajaran. Bandung: Remaja Rosdakarya. 
Jurnal Pendidikan Kewarganegaraan

Vol. 6 No. 1 Maret 2019

Schwab, K. (2016). The Fourth Industrial Revolution. Switzerland: World Economic Forum.

Schwab, K., \& Samans, R. (2016). "The Future of Jobs The Era Fourth Industrial Revolution." Switzerland. www.weforum.org.

Suhada, I. (2017). Konsep Dasar IPS. Bandung: Rosdakarya.
Journal of Civics and Education Studies p-ISSN 2302-0865 | e-ISSN 2621-346X

Supardan, D. (2015). Pembelajaran Ilmu Pengetahuan Sosial Perspektif Filosofi dan Kurikulum. Jakarta: Bumi Aksara.

Wardini, A. K. (2018). "Human Capital dan Keunggulan Bersaing di Era Industri 4.0." Universitas Terbuka. http://repository.ut.ac.id/7889/1/ora si-13nov2018.pdf. 